\title{
Heroes and Villains: The Relationship between Pitch Tessitura and Sociability of Operatic Characters
}

\author{
DANIEL SHANAHAN \\ Louisiana State University \\ DAVID HURON[1] \\ Ohio State University
}

\begin{abstract}
Research in speech prosody and ethology suggests that pitch height indexes positive and negative social affects, in the sense that higher pitched voices are used to convey friendliness, whereas lower pitched voices are used to convey aggression (Bolinger, 1964). Research concerning animal calls suggests that this association generalizes to many species. In a study of the calls for 56 species, Morton $(1977,1994)$ proposed a sound-size model in which large size (and low pitch) is associated with aggression, whereas small size (and high pitch) is associated with friendliness, fear, or appeasement. We examine whether this association can be observed in music. Specifically, the results of three studies are reported in which the pitch-height of various voices is related to estimates of the sociability of the corresponding operatic characters. Results indeed indicate an association between lower-pitched voices and less sociable characters, in contrast to higher-pitched voices being associated with more sociable characters. In addition, older male characters tend to exhibit lower-pitched voices, consistent with known physiological changes (Linville, 2004; Reubold, Harrington \& Kleber, 2010).
\end{abstract}

Submitted 2012 September 5; accepted 2014 October 8.

KEYWORDS: tessitura, pitch, sociability, opera, personality

\section{INTRODUCTION}

PITCH serves many functions in music. In particular, it provides the principal dimension for conveying modality, melodic contour, and inflection. At the same time, pitch also conveys some rather gross properties of emotional tenor (e.g., Ladd, 2008; Vassière, 1983). The use of pitch to convey affect is well documented in the case of speech prosody. For example, research by Bolinger, Ohala, and others has established that vocal pitch height (F0) is perceived to be associated with social cues for dominance and submissiveness. Dwight Bolinger (1964) carried out a cross-cultural study, and found that low or falling vocal pitch is associated with authority, threat, aggression, and confidence. Bolinger also showed that, conversely, high or rising vocal pitch is associated with politeness, deference, submissiveness and lack of confidence. Apart from humans, the relationship between pitch and affective intent can also be observed in non-human animals. Eugene Morton (1977, 1994) reviewed reports of vocalizations for 56 species as observed by ethologists. In general, low-pitched sounds are associated with aggressive signaling whereas high-pitched sounds are associated with friendly, fearful, or appeasing signals - all having submission as a common denominator.

In the case of music, Huron, Kinney and Precoda (2006) showed that melodies are perceived by listeners as more polite or submissive when transposed up in pitch, and as more heavy or threatening when transposed down in pitch (see also Morton, 2006). This result is consistent with the view that listeners apply a sound-size model when listening in purely musical contexts and that the effect is not limited to speech.

Although listeners may interpret transposed versus untransposed music as consistent with these affective connotations, the study by Huron et al. (2006) does not address the question whether composers actively make use of pitch height to convey specific affective content. Is it the case that musicians 
intentionally use higher pitches to convey socially affiliative connotations? Conversely, is it the case that musicians intentionally use lower pitches to convey socially antagonistic connotations?

Since the prosodic and ethological evidence relates explicitly to social interaction, the most appropriate place to observe a possible role is in music where some social relationship is explicitly portrayed. In abstract instrumental music, it would be hard to test or establish any putative relationship. Suitable music could include programmatic genres such as music theatre and opera. In these idioms, it is common to have singers portray various positive and negative social roles, such as heroes and villains. Accordingly, one might predict that heroic, friendly, or positive social roles would favor higher pitches, whereas villainous, menacing, unfriendly, or negative social roles would favor lower pitches.

Rather than examine the specific pitch content of the music, a useful simplification might focus on the ranges of the voices. In all of these genres, it is common for different roles to be identified with different vocal tessituras, such as coloratura, soprano, contralto, tenor, baritone, and bass. Accordingly, in this study, we use a correlational approach to examine the potential relationship between voice tessitura and the sociability of a character.

\section{HYPOTHESES}

Formally, we may state our hypothesis as follows:

H. There is an association between the vocal tessitura and estimated sociability of the corresponding character in operatic works.

The principal determinant of vocal pitch range is the gender of the singer. Since sex roles often reflect different social norms in different cultures, one would expect that gender is a confounding variable. Accordingly, we propose to carry out independent tests that both examine sex-related patterns, as well as tests that control for the sex of the singer/character. Specifically, we propose to test the following three hypotheses:

H1. Female roles are more sociable than male roles in opera.

H2. Higher-tessitura female roles are more sociable than lower tessitura female roles.

H3. Higher-tessitura male roles are more sociable than lower tessitura male roles.

One further confound relates to the use of castrato voices, counter-tenor voices singing in falsetto, as well as the common plot device of cross-dressing or sex-role reversals. In order to minimize these potentially confounding variables, we elected to exclude these vocal types and characters from our sampling.

In brief, we propose to test our hypotheses using two contrasting correlational approaches. In the first approach we begin with the voice tessituras for different operatic roles and determine the character quality. In the second approach we begin by classifying roles according to estimated sociability and then determine the associated vocal tessituras for each role. In both cases, we will test the prediction that there is a positive correlation between sociability and vocal tessitura.

\section{STUDY \#1: PRO-SOCIAL AND ANTI-SOCIAL CHARACTERS IN OPERA}

Social psychologists define pro-social behavior as altruistic behavior intended to benefit another person. Anti-social behavior may be regarded as self-centered, or behavior taken without regard for the repercussions for other individuals (Eisenberg, Fabes \& Spinrad, 2007). Examples of pro-social character traits include individuals who are helping, sharing, donating, cooperating, and volunteering (Brief \& Motowidlo, 1986). More broadly, pro-social traits include individuals who are friendly, cooperative, helpful, compassionate, charitable, or conscientious. Examples of anti-social character traits include individuals who are greedy, obnoxious, vindictive, belligerent, aggressive, or egocentric. 


\section{Procedure}

We began our first study by searching the Internet using the key terms "opera heroes" and "opera villains." This led us to two 2-CD compilations produced by the Opera d'Oro company, entitled Opera's Greatest Heroes and Opera's Super Villains (Anonymous, 2002a; 2002b). The combined four CDs include some 68 arias by 24 composers. In effect, these CDs provide a convenience sample in which the sociability of the characters has been determined by the producers of these compilations. Our hypotheses might be tested simply by counting the number of male and female characters classified as "Greatest Heroes" or "Super Villains" and also determining the distributions of high and low voices in each of the collections.

For the purposes of this study, we will assume that commonly identified "heroes" would rate high on sociability, whereas commonly identified "villains" represent characters who rate low on sociability.

The performers for each recording are identified on the $\mathrm{CD}$, and we independently confirmed the vocal range of the singer using easily available promotional material (each singer (self-)identified range). For example, Maria Callas is a self-described soprano, Enrico Caruso is characterized as a tenor, and Feodor Chaliapin is characterized as a bass.

\section{Results}

The results are summarized in Figure 1. Of the 68 characters, only three were women. In light of the small female sample, Figure 1 is limited to male characters. Villains are plotted using solid black bars whereas heroes are plotted in light grey bars. For thirty male heroes, the vocal ranges include 1 bass, 2 baritones, and 27 tenors. For thirty-eight male villains, the vocal ranges include 13 basses, 16 baritones, 4 bass/baritones, and 2 tenors. (In the case of female voices, there were no characters identified as heroes, with three of three villains identified as having soprano ranges.)

In light of the obvious trends in Figure 1, no statistical test was deemed necessary. In general, the results are consistent with the hypothesis that pro-social (or good person) voices are higher-although we only have sufficient data for male voices.

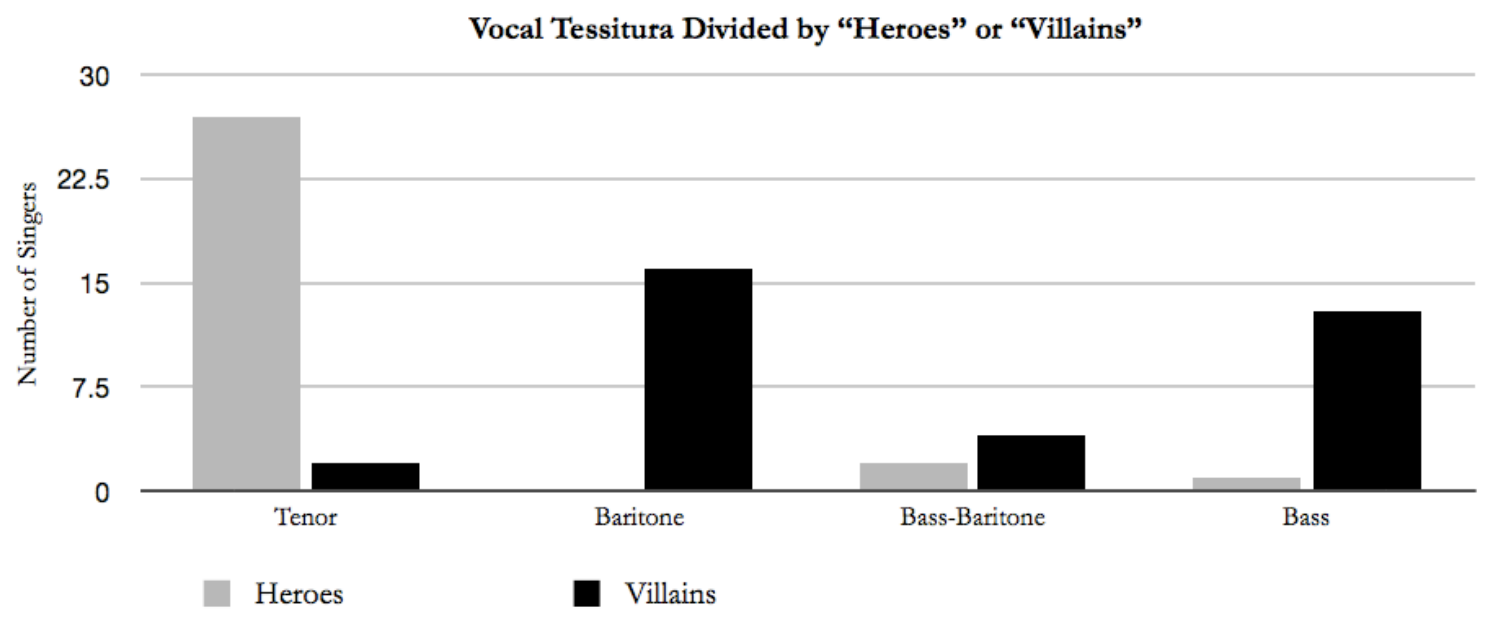

Fig 1. Vocal tessituras for 65 male opera characters deemed a priori to be either "heroes" or "villains."

\section{Discussion}

The results for our first study seem to conform to a widespread musical intuition. However, relying on the convenience sample provided by the two double-set CDs introduces several potential biases. As already noted, there is a marked paucity of female characters. In addition, we found that the compilations exhibit a strong reliance on the works of Verdi, and a relative abundance of German opera. Although Verdi is 
obviously a very important opera composer, and German opera is similarly important, one would be more secure about the results if a broader sample of materials was employed.

Another problem with this study is that there is considerable opportunity for selection bias. It could very well be the case that the producer's selection of heroes and villains was based on an a priori assumption that tenors (in particular) sing heroic roles. Moreover, the materials assembled for these recordings are likely to be dictated by such factors as the copyright status of the available recordings, and the popularity of the different singers.

Another difficulty with this study is the assumption that heroes and villains are appropriate operationalizations of the concept of sociability. One might well agree that "villains" are paradigmatic examples of "anti-social" characters. However, the case of "heroes" is more contentious. Heroes are typically individuals who engage in decisive action (often violent). Heroes are not necessarily paragons of friendliness, cooperation, compassion, or charity.

Accordingly, we initiated a second study, with the aim of addressing the sampling problems encountered in our first study. Specifically, we aimed to reduce both the gender bias and the bias toward heroic rather than villainous characters, and to make use of a more formal sampling method.

\section{STUDY \#2: SOCIABILITY AND TESSITURA}

In brief, our second study involved reading plot summaries for a sample of operas, estimating the sociability of the characters, and correlating these estimates with the corresponding tessiture of the characters. Plot summaries were obtained from a standard reference book on opera, New Kobbe's Opera Book (Harewood and Peattie, 1997). This volume contains plot summaries for 502 of the best-known Western operas. Plot summaries are typically 1-2 pages in length.

\section{Procedure}

Our sample was assembled using a systematic sampling method where we chose every $15^{\text {th }}$ opera from the alphabetical index of composers. In order to avoid over-representation of especially prolific composers, only a single opera was sampled from any given composer. This procedure resulted in 33 sampled operas, including works by Adam, Beethoven, Berlioz, Blake, Britten, Charpentier, Donizetti, Dukas, Gershwin, Goldmark, Handel, Haydn, Hindemith, Janáček, Martinů, Massenet, Meyerbeer, Mozart, Nielsen, Poulenc, Puccini, Reyer, Rossini, Roussel, Schubert, Sondheim, Strauss, Stravinsky, Tippett, Verdi, Vir, Weber, and Zemlinski.

Plot summaries were read independently by the two authors. Each author rated the pro-social behavior for various characters. Only those characters were rated for which the individual researcher felt the plot summary provided sufficient detail to judge sociability. Ratings were made using a five-point scale, where 5 represents the most pro-social, 1 represents the most anti-social, and 3 represents some neutral social characterization. Although authors were aware of the hypothesis, the tessitura of each character was not visible to the author whilst rating character's respective sociability.

Rater 1 rated 87 characters, whereas Rater 2 rated 99 characters. In total, the sociability of some 117 unique characters was rated, while 66 characters were rated by both authors.

\section{Results}

A simple test of reliability of the pro-social ratings is to measure the correlation between the sociability estimates provided by the two authors for the 66 characters rated by both. The inter-rater reliability was measured to be $+.82(d f=64, p<.01)$. In light of this high correlation, the ratings for both authors were averaged together for the 66 characters rated in common. These values were supplemented by the 51 characters rated by only a single rater - resulting in 117 characters, 59 male and 58 female.

The tessiture for all of the female characters were classified as either soprano, mezzo-soprano, or contralto. The tessiture can be regarded as ordinal data and coded on a three-point scale. Accordingly, we can calculate the rank-order correlation between the sociability ratings and the voice tessitura. Similarly, all of the male characters were classified as either tenor, baritone, bass-baritone, or bass. Once again, these can be coded as ranked data on a four-point scale and a rank-order correlation calculated with respect to the 
sociability ratings. Finally, we can compare the average sociability ratings for the female characters versus the male characters.

In the case of hypothesis 1 , the average sociability ratings for the females characters (3.66) were indeed found to be slightly higher than the average sociability ratings for male characters (3.50), however, this difference proved not to be statistically significant $(t=0.498 ; d f=115 ; p=.619)$. In the case of hypothesis 2, we calculated the rank-order correlation (Kendall's tau) between estimated sociability and voice tessitura. We found a significant relationship between the estimated sociability of height of voice for female characters $(T=.672 ; d f=56 ; p<.0001)$. With regard to the effect size, the adjusted $R^{2}$ was .43 suggesting that just under half of the variance in estimated sociability can be linked to vocal tessitura.

In the case of hypothesis 3 , we similarly calculated the rank-order correlation between estimated sociability and voice-type for male voices. Once again, we found a significant result ( $\boldsymbol{T}=.567 ; d f=57 ; p=$ .0002 ). The adjusted $R^{2}$ was .30 , suggesting that about a third of the variance in estimated sociability for male characters can be linked to tessitura.

\section{Discussion}

In reading the opera scenarios for Study \#2, we informally noticed two other factors that appeared to relate to vocal tessitura. Specifically, older characters seemed to be more likely to be assigned lower tessiture. In addition, "authoritative" roles also seemed to be more likely linked to lower tessiture. That is, characters like kings, queens, mayors, judges, generals, wizards, witches, priests, monks, and wise men/women seemed more likely to have lower voices.

In light of these informal post hoc observations, we carried out a third study that would explicitly test the possible influence of these additional factors as a priori hypotheses.

\section{STUDY \#3: ROLE OF AGE, AUTHORITY, AND SOCIABILITY ON TESSITURA}

For our third study we proposed to test two additional hypotheses:

H4. Older characters are more likely to be associated with lower-tessitura roles.

H5. Authoritative characters are more likely to be associated with lower-tessitura roles.

In order to test these hypotheses, we a priori decided to pursue a multiple regression analysis. That is, we would randomly select a sample of opera scenarios, and rate characters according to three criteria:

1. Estimated sociability of the character.

2. Estimated age of the character.

3. Estimated authority of the character, where authority is defined as holding a position (formal or informal) of moral or political responsibility, holding an exalted position due to special knowledge or wisdom, or having magical or super-natural powers. Notice that a person in authority may be benevolent or malevolent: the key is that they are able to exercise some kind of power.

Once again, sociability was estimated using a 5-point impressionistic scale. Age was coded as estimated age (in years). For a handful of mythical characters, ages were rated on the basis of the characterization rather than some presumed agelessness; hence, characters like Venus and the Dew Fairy were coded as rather youthful, whereas an immortal witch was coded as elderly. When plots took place over long spans of time, we used the age of the characters in the central acts of the opera. For example, in the case of Enesco's Oedipe, the action takes place over four decades; since the opera contains four acts, we a priori coded the character's ages according to Act 2. Authority was estimated using a 5-point impressionistic scale ranging from 1 (little or no authority) to 5 (high authority). Once again, characters scoring high on authority included kings, queens, mayors, judges, generals, wizards, witches, priests, monks, and wise persons. All ratings were done by both raters independently. 


\section{Procedure}

Once again, we sampled operas from the New Kobbe's Opera Book. Specifically, 23 operas were randomly sampled from the index, avoiding more than one opera by a single composer, and avoiding operas previously sampled. Specifically, we sampled operas by Arrieta, Bellini, Birtwistle, Busoni, Dallapiccola, Enesco, Glinka, Gounod, Henze, Humperdinck Lehár, Massenet, Mennotti, Millöcker, Mussorgsky, Orff, Rameau, Rimsky-Korsakov, Sallinen, Smetana, Tchaikovsky, Vaughan Williams, Wagner, and Weir. Once again, the two authors read each plot summary and independently estimated the sociability, the age, and the authoritativeness for each character.

\section{Results}

Appendix 1 identifies the sampled operas, including composer, century, and nationality. In addition, the appendix identifies each sampled character, along with the corresponding tessitura, as well as average estimates for sociability, age, and authority. The data were analyzed using multiple regression, where the predicted variable is the voice tessitura (coded as ordinal or rank order data), with four predictor variables: (1) character gender, (2) estimated age, (3) estimated sociability, and (4) estimated authoritativeness. Notice that one would expect a large amount of shared variance between age and authoritativeness: kings, judges, generals, etc., are more likely to be older. Using a standard Stepwise or Forward approach is likely to discard one or another of these variables due to the shared variance. Accordingly we a priori elected to use the Backward Entry method. This has the effect of reducing type II errors (e.g., Field, 2005). That is, it is less likely to discard a variable that might exhibit a true effect on the predicted variable. Also, one might anticipate that the biggest effect on vocal tessitura will be gender. Consequently, we resolved a priori to carry out separate analyses for the female and male characters, with the expectation that controlling for gender would allow the possible effects of the other variables to be more apparent.

The results of our analyses are summarized in Tables 1 and 2a-c. Table 1 shows the correlation matrix for the combined male/female data. As expected, of the predictor variables, Authoritativeness and Age exhibit the highest correlation (+.58). Also, as expected, the variable most correlated with tessitura is Gender. This is followed by Authoritativeness (-.37), Sociability (+.32), and Age (-.30). Shared variance is evident throughout the table. Marked $(*)$ values indicate statistical significance at the 95 percent confidence level after correcting for multiple tests.

Table 1. Correlation Matrix (both male/female characters) $\mathrm{df}=115$.

$\begin{array}{llllll} & \text { Tessitura } & \text { Sociability } & \text { Gender } & \text { Age } & \text { Authoritativeness } \\ \text { Tessitura } & 1.00 & & & & \\ \text { Sociability } & .32^{*} & 1.00 & & & \\ \text { Gender } & .86^{*} & .14 & 1.00 & & \\ \text { Age } & -.30^{*} & -.32^{*} & -.15 & 1.00 & \\ \text { Authoritativeness } & -.37^{*} & -.20^{*} & -.31^{*} & .58^{*} & 1.00\end{array}$

Tables $2 \mathrm{a}-\mathrm{c}$ present the results of the multiple regression analyses. Table $2 \mathrm{a}$ shows the combined data for both male and female characters. As can be seen, the elimination of authoritativeness has no effect on the model accuracy, suggesting that authoritativeness is unimportant. Sociability, gender, and age offer a combined model that accounts for 85 percent of the variance (adjusted). Tables $2 \mathrm{~b}$ and $2 \mathrm{c}$ show separated results for the male and female characters respectively. 
Table 2a. Regression Analysis Results (combined male/female characters). $\mathrm{df}=115$

$\begin{array}{lccc} & \boldsymbol{R} & \boldsymbol{R}^{2} & \text { Adjusted } \boldsymbol{R}^{2} \\ \begin{array}{l}\text { Authoritativeness, Sociability, } \\ \text { Gender, Age }\end{array} & .92 & .85 & .84 \\ \text { Sociability, Gender, Age } & .92 & .85 & .85\end{array}$

Table 2b. Regression Analysis Results (male characters only). df $=57$

$\begin{array}{lcccc} & \boldsymbol{R} & \boldsymbol{R}^{2} & \text { Adjusted } \boldsymbol{R}^{2} \\ \text { Authoritativeness, Sociability, Age } & .47 & .22 & .18 \\ \text { Sociability, Age } & .46 & .21 & .19\end{array}$

Table 2c. Regression Analysis Results (female characters only). df $=56$

$\begin{array}{llll} & \boldsymbol{R} & \boldsymbol{R}^{2} & \text { Adjusted } \boldsymbol{R}^{2} \\ \text { Authoritativeness, Sociability, Age } & .61 & .37 & .33 \\ \text { Sociability, Age } & .60 & .36 & .33 \\ \text { Sociability } & .59 & .35 & .33\end{array}$

\section{Discussion}

Not surprisingly, the results for Study \#3 indicate that gender plays the biggest role: female voices are higher in pitch than male voices. More interestingly, estimated age and sociability were present in all of the models. In general, younger opera characters exhibit higher pitch than older characters. At the same time, those characters rated as having the highest pro-social traits also exhibit higher pitched voices. As expected, there is a large shared variance between authoritativeness and age, which makes it difficult to determine the independent effect of either factor. At face value, the analysis suggests that age is the dominant effect with authoritativeness making no significant independent contribution. With regard to age, it is known that vocal pitch tends to drop for both males and females, at least until middle age. For females, the pitch of the voice drops continuously from adolescence onward (Reubold, Harrington \& Kleber, 2010). For males, the pitch of the voice drops from adolescence to roughly middle age, but in advanced old age, the pitch then rises (Linville, 2004).

\section{CONCLUSION}

Altogether, the three correlational studies offer converging evidence consistent with an association between pitch tessitura and sociability. Those opera characters deemed to exhibit the highest sociability also exhibited the highest tessitura.

In our first study, we saw that, of 30 male characters nominally deemed "heroes," the overwhelming majority (27) were tenors. Conversely, of 34 characters nominally deemed "villains," nearly all (32) were either basses or baritones. In the words of the American baritone, Leonard Warren, "Tenors are noble, pure and heroic and get the soprano, if she has not tragically expired before the final curtain. But baritones are born villains in opera. Always the heavy and never the hero — that's me" (Shapiro, 1977; 171). Although this categorization is ubiquitous in opera, composers have sometimes played against this trope. For example, Puccini's Madame Butterfly utilizes an "evil tenor" in the character Pinkerton, and the role of Nero in Monteverdi's L'incoronazione di Poppea is often performed by a female soprano (while the 
role was originated by a castrato). The latter example brings up a crucial point: the majority of the examples were derived from $19^{\text {th }}$ century opera, with a few examples from preceding centuries, and only a handful of $20^{\text {th }}$-century operas. The role of castrati in $17^{\text {th }}$ and $18^{\text {th }}$ century operas provides an interesting caveat for this study: although they often sang the female lead roles in operas in the $17^{\text {th }}$ century, castrati frequently sang the male leads in the $18^{\text {th }}$ century, especially as the popularity of castrati such as Farinelli and Pacchierotti soared. In many ways, this is a performance practice that might not apply to the majority of the operas examined in the current study, but should nevertheless be understood as an important caveat.

In our second study, we estimated the degree of pro-sociability for 117 characters from 33 operas. We found that estimated sociability accounted for about 40 percent of the variance in vocal tessitura for female voices, and about 30 percent of the variance in vocal tessitura for male voices. Those opera characters judged most sociable tended to exhibit higher vocal ranges.

In our third study, we explicitly examined the combination of estimated sociability, age, and authoritativeness. We found that authoritativeness and age share considerable variance. In this study, the largest effect was attributed to gender (not surprisingly: female roles tend to exhibit higher voices). Note, once again, that it is possible that some of the variance attributed to gender might arise from sociability, since the least sociable characters are more likely to be male. Both estimated age and sociability proved to be significant, with older characters tending to be associated with lower voices, and more sociable characters tending to be associated with higher voices.

In general, the results are consistent with common musical intuitions. Moreover, the results are also consistent with cross-cultural prosody research in speech, and with ethological principles regarding animal calls (Bolinger, 1964; Morton, 1977, 1994). The results suggest that female roles tend to be more sociable than male roles in (primarily $19^{\text {th }}$-century) opera; higher-tessitura female roles are more sociable than lower tessitura female roles, and higher-tessitura male roles are more sociable than lower-tessitura male roles. Like growling bears, the most threatening sounds tend to be low in pitch.

\section{NOTES}

[1] Please address all correspondence to: Daniel Shanahan, School of Music, Louisiana State University, Baton Rouge Louisiana, 70803, or David Huron, School of Music, 1866 College Rd., Columbus, OH, 43210, U.S.A.

\section{REFERENCES}

Anonymous (2002a). Opera's Greatest Heroes, Opera D'Oro, CD OPD-8007.

Anonymous (2002b). Opera's Super Villains, Opera D'Oro CD OPD-8008.

Bolinger, D. L. (1964). Intonation across languages. In J. H. Greenberg, C. A. Ferguson \& E. A. Moravcsik (Eds.), Universals of Human Language: Phonology (Vol. 2) (pp. 471-524). Stanford, Calif.: Stanford University Press.

Brief, A. P., \& Motowidlo, S. J. (1986). Prosocial organizational behaviors. The Academy of Management Review, 11(4), 710-725.

Eisenberg, N., Fabes, R. A., \& Spinrad, T. L. (2007). Prosocial Development. Handbook of Child Psychology, Hoboken NJ: Wiley. DOI:10.1002/9780470147658.chpsy0311. ISBN 0-470-14765-2.

Field, A. (2005). Discovering statistics using SPSS (2nd edition). London: Sage Publications.

Harewood, The Earl of, \& Peattie, A. (1919/1997). The new Kobbe's opera book (11th edition). New York: Putnam. First published as G. Kobbe (1919) The complete opera book. New York.

Huron, D., Kinney, D., \& Precoda, K. (2006). Influence of pitch height on the perception of submissiveness and threat in musical passages. Empirical Musicology Review, 1(3), 170-177. 
Ladd, D. R. (2008). Intonational phonology (2nd edition). Cambridge: Cambridge University Press.

Linville, S. E. (2004, October 19). The aging voice. The ASHA Leader. Retrieved from http://www.asha.org/Publications/leader/2004/041019/041019e.htm

Morton, E. S. (1977). On the occurrence and significance of motivation-structural rules in some bird and mammal sounds. The American Naturalist, 111, 855-869.

Morton, E. S. (1994). Sound symbolism and its role in non-human vertebrate communication. In L. Hinton, Nichols \& J. Ohala (Eds.), Sound Symbolism (pp. 348-365). Cambridge: Cambridge University Press.

Morton, E. S. (2006). Commentary on "The influence of pitch height on the perception of submissiveness and threat in musical passages" by David Huron, Daryl Kinney, and Kristin Precoda. Empirical Musicology Review, 1(3), 178-179.

Patel, A. D. (2008). Music, language, and the brain. Oxford: Oxford University Press.

Reubold, U., Harrington, J., \& Kleber, F. (2010). Vocal aging effects on F0 and the first formant: A longitudinal analysis in adult speakers. Speech Communication, 52, 638-651.

Shapiro, N. (1977). An encyclopedia of quotations about music. New York: Da Capo Press.

Vassière, J. (1983). Language-independent prosodic features. In A. Cutler \& D. R. Ladd (Eds.), Prosody: Models and measurements (pp. 53-66.). Berlin: Springer. 


\section{APPENDIX 1}

\section{Opera Plots Evaluated for Sociability, Age, Authority, and Tessitura}

\begin{tabular}{|c|c|c|c|c|c|c|c|c|}
\hline Opera & Composer & Nationality & Year & Character & $\begin{array}{c}\text { Average } \\
\text { Sociability }\end{array}$ & Age & Authority & Tessitura \\
\hline \multirow[t]{5}{*}{ Marina } & Arrieta & Spain & 1871 & & & & & \\
\hline & & & & Marina & 5 & 22.5 & 2.5 & 7 \\
\hline & & & & Jorge & 4.5 & 27.5 & 4 & 4 \\
\hline & & & & Pascual & 1 & 30 & 3 & 2 \\
\hline & & & & Alberto & 3.5 & 25 & 4.5 & 3 \\
\hline \multirow[t]{8}{*}{ I Puritani } & Bellini & Italian & 1835 & & & & & \\
\hline & & & & Lord Valton & 3.5 & 55 & 5 & 2 \\
\hline & & & & Giorgio & 1.5 & 42.5 & 3.5 & 2 \\
\hline & & & & Arturo & 5 & 27.5 & 3.5 & 4 \\
\hline & & & & Riccardo & 1.5 & 27.5 & 4 & 3 \\
\hline & & & & Enrichetta & 3.5 & 45 & 3.5 & 7 \\
\hline & & & & Elivra & 5 & 19 & 2 & 7 \\
\hline & & & & Bruno & 3 & 40 & & \\
\hline \multirow[t]{7}{*}{ Gawain } & Birtwistle & English & 1991 & & & & & \\
\hline & & & & Morgan le Fay & 1.5 & 42.5 & 4 & 7 \\
\hline & & & & $\begin{array}{l}\text { Lady de } \\
\text { Hautdesert }\end{array}$ & 2 & 30 & 3 & 6 \\
\hline & & & & King Arthur & 4 & 55 & 4.5 & 4 \\
\hline & & & & Guinevere & 4 & 45 & 3.5 & 7 \\
\hline & & & & Gawain & 4.5 & 26.5 & 4 & 3 \\
\hline & & & & $\begin{array}{l}\text { Green } \\
\text { Knight/Bertilak }\end{array}$ & 1 & 28.5 & 4.5 & 2 \\
\hline \multirow{6}{*}{$\begin{array}{l}\text { The } \\
\text { Immortal } \\
\text { Hour }\end{array}$} & Boughton & English & 1914 & & & & & \\
\hline & & & & & & & & \\
\hline & & & & Eochaidh & 4 & 50 & 5 & \\
\hline & & & & Dalua & 2 & 60 & 5 & \\
\hline & & & & Etain & 3 & 20 & 3 & \\
\hline & & & & & & & & \\
\hline \multirow{4}{*}{ Arlecchino } & Busoni & Italian & 1917 & & & & & \\
\hline & Busonl & ttanan & 1917 & Matteo & 3 & 27.5 & 1.5 & 3 \\
\hline & & & & Arlecchino & 2.5 & 27.5 & 3 & 0 \\
\hline & & & & Colombina & 4 & 27.5 & 1.5 & 6 \\
\hline \multirow[t]{8}{*}{ Ulisse } & Dallapiccola & Italian & 1968 & & & & & \\
\hline & & & & Ulisse & 4 & 55 & 4 & 3 \\
\hline & & & & Calypso & 4 & 30 & 2.5 & 7 \\
\hline & & & & Penelope & 5 & 47.5 & 3 & 7 \\
\hline & & & & Nausicaa & 3.5 & 22.5 & 2.5 & 7 \\
\hline & & & & King Alicinoo & 3 & 55 & 4 & 1 \\
\hline & & & & Circe & 1.5 & 32.5 & 4 & 6 \\
\hline & & & & Antinoo & 2.5 & 27.5 & 2.5 & 3 \\
\hline
\end{tabular}




\begin{tabular}{|c|c|c|c|c|c|c|c|c|}
\hline Opera & Composer & Nationality & Year & Character & $\begin{array}{c}\text { Average } \\
\text { Sociability }\end{array}$ & Age & Authority & Tessitura \\
\hline & & & & Pisandro & 2 & 27.5 & 2.5 & 3 \\
\hline & & & & Eurimaco & 1.5 & 27.5 & 2.5 & 4 \\
\hline & & & & Telemaco & 4 & 27.5 & 2.5 & 5 \\
\hline \multirow[t]{7}{*}{ Oedipe } & Enescu & Romanian & 1936 & & & & & \\
\hline & & & & Oedipe & 4.5 & 45 & 5 & 2 \\
\hline & & & & Tiresias & 3 & 37.5 & 3.5 & 2 \\
\hline & & & & Creon & 1 & 27.5 & 2.5 & 1 \\
\hline & & & & King Laius & 1.5 & 47.5 & 3.5 & 4 \\
\hline & & & & Queen Jocaste & 3 & 37.5 & 3 & 6 \\
\hline & & & & Antigone & 5 & 22.5 & 1.5 & 7 \\
\hline \multirow[t]{8}{*}{$\begin{array}{l}\text { Russlan and } \\
\text { Lyudmila }\end{array}$} & Glinka & Russian & 1846 & & & & & \\
\hline & & & & Lyudmila & 5 & 19 & 1.5 & 7 \\
\hline & & & & Russlan & 3.5 & 23 & 3 & 3 \\
\hline & & & & Ratmir & 2.5 & 32.5 & 3 & 6 \\
\hline & & & & Farlaf & 2.5 & 30 & 3 & 1 \\
\hline & & & & Finn & 4.5 & 30 & 3 & 4 \\
\hline & & & & Naina & 1 & 30 & 4 & 6 \\
\hline & & & & Tchernomor & 1.5 & 65 & 5 & 0 \\
\hline \multirow{5}{*}{$\begin{array}{l}\text { Romeo et } \\
\text { Juliette }\end{array}$} & Gounod & French & 1867 & & & & & \\
\hline & & & & Juliet & 5 & 15 & 2 & 7 \\
\hline & & & & Tybalt & 1 & 18 & 3.5 & 4 \\
\hline & & & & Romeo & 4 & 16 & 2.5 & 4 \\
\hline & & & & Mercutio & 1.5 & 17.5 & 2.5 & 3 \\
\hline \multirow{9}{*}{$\begin{array}{l}\text { Konig } \\
\text { Hirsch }\end{array}$} & Henze & German & 1956 & & & & & \\
\hline & & & & Leandro & 5 & 25 & 4 & 4 \\
\hline & & & & Costanza & 4.5 & 22.5 & 2 & 7 \\
\hline & & & & Tartaglia & 1.5 & 42.5 & 4.5 & 2 \\
\hline & & & & ScollatellaI & 2.5 & 22.5 & 1.5 & 7 \\
\hline & & & & ScollatellaII & 2.5 & 22.5 & 1 & \\
\hline & & & & SocllatellaIII & 2.5 & 22.5 & 1 & 6 \\
\hline & & & & ScollatellaIV & 2.5 & 22.5 & 1 & 5 \\
\hline & & & & Ciglotti & 5 & & $?$ & 0 \\
\hline \multirow{8}{*}{$\begin{array}{l}\text { Hansel und } \\
\text { Gretel }\end{array}$} & Humperdinck & German & 1893 & & & & & \\
\hline & & & & Hansel & 5 & 11 & 1 & 6 \\
\hline & & & & Gretel & 4.5 & 9 & 1 & 7 \\
\hline & & & & Witch & 1 & 65 & 4.5 & 6 \\
\hline & & & & Gertrude & 2 & 32.5 & 2.5 & 7 \\
\hline & & & & Peter & 2 & 37.5 & 2.5 & 3 \\
\hline & & & & Sandman & 4 & 27.5 & 2 & 7 \\
\hline & & & & DewFairy & 3 & 17.5 & 2 & 7 \\
\hline
\end{tabular}




\begin{tabular}{|c|c|c|c|c|c|c|c|c|}
\hline Opera & Composer & Nationality & Year & Character & $\begin{array}{c}\text { Average } \\
\text { Sociability }\end{array}$ & Age & Authority & Tessitura \\
\hline \multirow{6}{*}{$\begin{array}{l}\text { Lustige } \\
\text { Witwe }\end{array}$} & Lehár & Hungarian & 1905 & & & & & \\
\hline & & & & $\begin{array}{l}\text { Baron Minko } \\
\text { Zeta }\end{array}$ & 3 & 45 & 4.5 & 1 \\
\hline & & & & Valencienne & 4 & 37.5 & 3 & 7 \\
\hline & & & & Count Danilo & 4.5 & 32.5 & 3 & 4 \\
\hline & & & & Hanna Glawari & 5 & 30 & 2.5 & 7 \\
\hline & & & & & 3 & & & \\
\hline \multirow[t]{5}{*}{ Hérodiade } & Massenet & French & 1881 & & 3 & & & \\
\hline & & & & Salome & 2.5 & 27.5 & 3.5 & 7 \\
\hline & & & & Herod & 3.5 & 52.5 & 5 & 3 \\
\hline & & & & Herodias & 2.5 & 47.5 & 4 & 6 \\
\hline & & & & John the Baptist & 5 & 31.5 & 2.5 & 4 \\
\hline \multirow{3}{*}{$\begin{array}{l}\text { The } \\
\text { Telephone }\end{array}$} & Menotti & Italian/American & 1965 & & & & & \\
\hline & & & & Lucy & 4.5 & 27.5 & 2.5 & 7 \\
\hline & & & & Ben & 5 & 27.5 & 2 & 3 \\
\hline \multirow[t]{6}{*}{ Die Kluge } & Orff & German & 1943 & & & & & \\
\hline & & & & The King & 2 & 35 & 5 & 3 \\
\hline & & & & Peasant & 3 & 35 & 1 & 1 \\
\hline & & & & Daughter & 4.5 & 19 & 2.5 & 7 \\
\hline & & & & Donkey man & 3.5 & 37.5 & 1 & 4 \\
\hline & & & & Mule man & 2 & 37.5 & 1 & 3 \\
\hline \multirow{9}{*}{$\begin{array}{l}\text { Castor et } \\
\text { Pollux }\end{array}$} & Rameau & French & 1737 & & & & & \\
\hline & & & & Venus & 5 & 22.5 & 3 & 7 \\
\hline & & & & Mars & 1 & 47.5 & 5 & 3 \\
\hline & & & & Castor & 4.5 & 27.5 & 3 & 4 \\
\hline & & & & Pollux & 4.5 & 27.5 & 3.5 & 1 \\
\hline & & & & Telaire & 5 & 22.5 & 2.5 & 7 \\
\hline & & & & Phebe & 1 & 22.5 & 2.5 & 7 \\
\hline & & & & Jupiter & 1.5 & 45 & 5 & 1 \\
\hline & & & & Minerva & 4 & & 5 & 7 \\
\hline \multirow[t]{8}{*}{ Tsar Saltan } & $\begin{array}{l}\text { Rimsky- } \\
\text { Korsakov }\end{array}$ & Russian & 1900 & & & & & \\
\hline & & & & Tsar Saltan & 3 & 57.5 & 5 & 1 \\
\hline & & & & Militrissa & 5 & 37.5 & 2.5 & 7 \\
\hline & & & & The Middle & 1.5 & 41 & 1.5 & 6 \\
\hline & & & & Eldest & 1.5 & 39.5 & 1.5 & 7 \\
\hline & & & & Barbarikha & 1 & 60 & 3 & 6 \\
\hline & & & & Prince Guidon & 5 & 22.5 & 4 & 4 \\
\hline & & & & Swan-Princess & 5 & 20 & 4 & 7 \\
\hline \multirow[t]{5}{*}{ The Palace } & Sallinen & Finnish & 1993 & & & & & \\
\hline & & & & King & 3.5 & 55 & 5 & 4 \\
\hline & & & & Constance & 5 & 42.5 & 3 & 7 \\
\hline & & & & Valmonte & 1.5 & 27.5 & 3 & 3 \\
\hline & & & & Kitty & 4 & 25 & 1.5 & 7 \\
\hline
\end{tabular}




\begin{tabular}{|c|c|c|c|c|c|c|c|c|}
\hline Opera & Composer & Nationality & Year & Character & $\begin{array}{c}\text { Average } \\
\text { Sociability }\end{array}$ & Age & Authority & Tessitura \\
\hline \multirow[t]{5}{*}{ Libuse } & Smetana & Czech & 1881 & & & & & \\
\hline & & & & Libuse & 5 & 27.5 & 4.5 & 7 \\
\hline & & & & Premysl & 5 & 27.5 & 2.5 & 3 \\
\hline & & & & Chrudos & 1 & 32.5 & 2 & 1 \\
\hline & & & & St'ahlav & 2 & 30 & 2 & 4 \\
\hline \multirow{4}{*}{$\begin{array}{l}\text { Queen of } \\
\text { Spades }\end{array}$} & Tchaikovsky & Russian & 1890 & & & & & \\
\hline & & & & Herman & 4.5 & 32.5 & 2 & 4 \\
\hline & & & & Countess & 3.5 & 57.5 & 4 & 6 \\
\hline & & & & Lisa & 4.5 & 25 & 2.5 & 7 \\
\hline \multirow[t]{5}{*}{$\begin{array}{l}\text { Poisoned } \\
\text { Kiss }\end{array}$} & $\begin{array}{l}\text { Vaughan } \\
\text { Williams }\end{array}$ & English & 1936 & & & & & \\
\hline & & & & Dispasacus & 1 & 47.5 & 5 & 2 \\
\hline & & & & Tormentilla & 5 & 22.5 & 3 & 7 \\
\hline & & & & Amaryllus & 4 & 22.5 & 3 & 4 \\
\hline & & & & $\begin{array}{l}\text { Empress } \\
\text { Persicaria }\end{array}$ & 1.5 & 42.5 & 4.5 & 6 \\
\hline \multirow[t]{6}{*}{ Lohengrin } & Wagner & German & 1850 & & & & & \\
\hline & & & & King of Germany & 3.5 & 55 & 5 & 1 \\
\hline & & & & Lohengrin & 5 & 27.5 & 5 & 4 \\
\hline & & & & Elsa & 4.5 & 25 & 2.5 & 7 \\
\hline & & & & Telramund & 1 & 30 & 3.5 & 3 \\
\hline & & & & Ortrud & 2.5 & 32.5 & 3 & 6 \\
\hline \multirow{4}{*}{$\begin{array}{l}\text { Night at the } \\
\text { Chinese } \\
\text { Opera }\end{array}$} & Weir & English & 1987 & & & & & \\
\hline & & & & Chao Lin & 5 & 19 & 3 & 3.5 \\
\hline & & & & $\begin{array}{l}\text { General Tu-an- } \\
\mathrm{Ku}\end{array}$ & 1 & 52.5 & 5 & 6 \\
\hline & & & & $\begin{array}{l}\text { Chao-the-Loyal- } \\
\text { Civil-Servant }\end{array}$ & 5 & 47.5 & 3 & 4 \\
\hline
\end{tabular}

